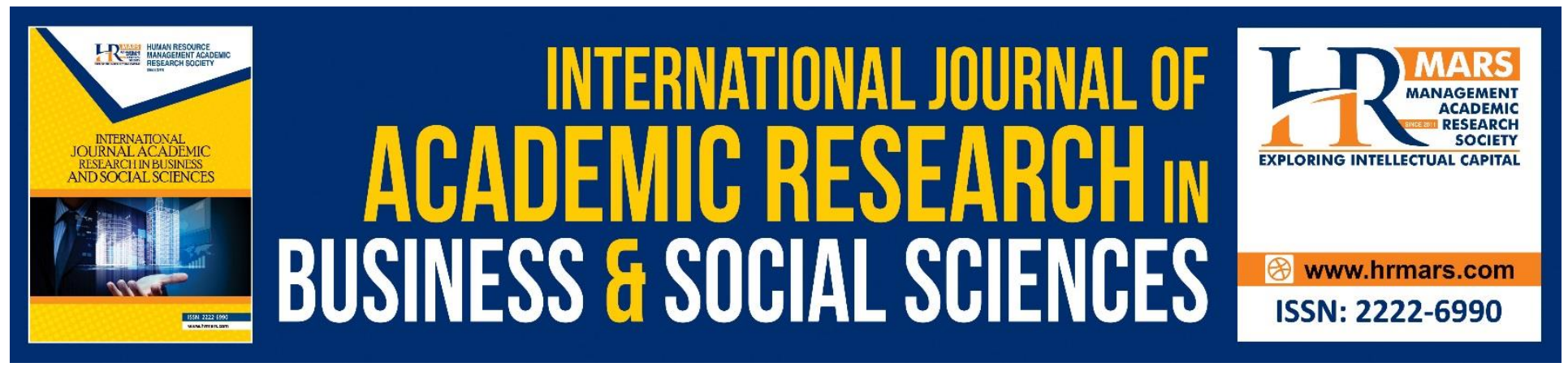

\title{
Developing Connection in Community of Practice: Positive Youth Development through Mentoring among Youth Leaders in Malaysia
}

Mohd Mursyid Arshad, Ismi Arif Ismail, Turiman Suandi, Zoharah Omar, Steven Eric Krauss

To Link this Article: http://dx.doi.org/10.6007/IJARBSS/v8-i12/5000

DOI: $10.6007 /$ IJARBSS/v8-i12/5000

Received: 29 Oct 2018, Revised: 17 Nov 2018, Accepted: 29 Nov 2018

Published Online: 18 Dec 2018

In-Text Citation: (Arshad, Ismail, Suandi, Omar, \& Krauss, 2018)

To Cite this Article: Arshad, M. M., Ismail, I. A., Suandi, T., Omar, Z., \& Krauss, S. E. (2018). Developing Connection in Community of Practice: Positive Youth Development through Mentoring among Youth Leaders in Malaysia. International Journal of Academic Research in Business and Social Sciences, 8(12), 123-133.

\section{Copyright: (C) 2018 The Author(s)}

Published by Human Resource Management Academic Research Society (www.hrmars.com)

This article is published under the Creative Commons Attribution (CC BY 4.0) license. Anyone may reproduce, distribute, translate and create derivative works of this article (for both commercial and non-commercial purposes), subject to full attribution to the original publication and authors. The full terms of this license may be seen at: http://creativecommons.org/licences/by/4.0/legalcode

Vol. 8, No. 12, 2018, Pg. 123 - 133

Full Terms \& Conditions of access and use can be found at http://hrmars.com/index.php/pages/detail/publication-ethics 


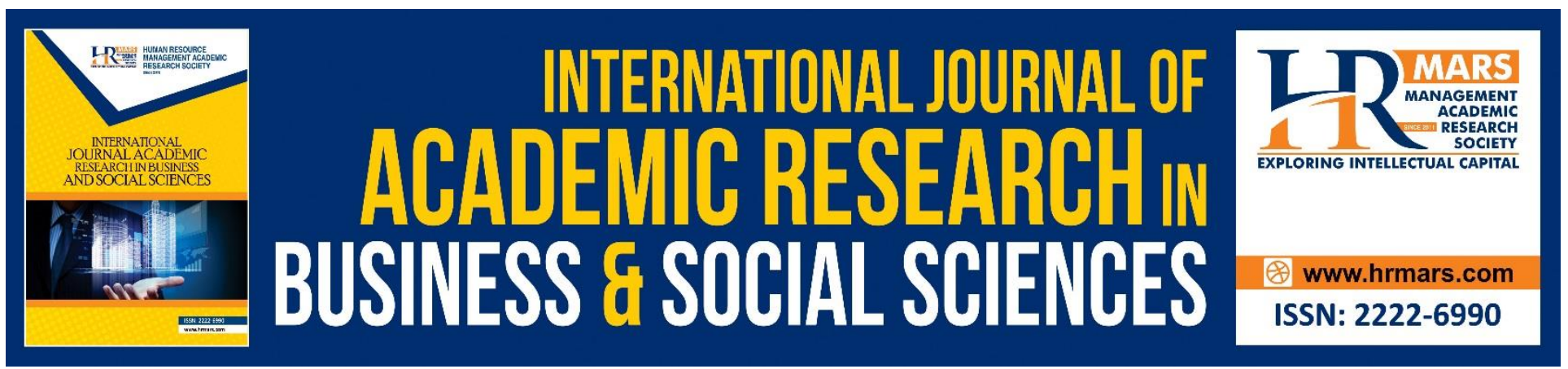

\title{
Developing Connection in Community of Practice: Positive Youth Development through Mentoring among Youth Leaders in Malaysia
}

\author{
Mohd Mursyid Arshad, Ismi Arif Ismail, Turiman Suandi, Zoharah \\ Omar, Steven Eric Krauss \\ Faculty of Educational Studies, Universiti Putra Malaysia, 43400 UPM Serdang, Selangor Darul \\ Ehsan, Malaysia
}

\begin{abstract}
Youth leadership development is a primary focus in Malaysia's development agenda as outlined in the 'Transformasi Nasional 2050' or TN 50 policy initiative. Research and practice concur that the involvement of young leaders can be strengthened through wider exposure to professional training and mentoring. Yet, mentoring offers a unique learning process that enhances youth development and strengthening connection within communities. The current study was conducted to explore the contribution of mentoring to positive youth development and mentees' sense of connection to the community and youth stakeholders. The study was conducted using a qualitative approach informed by the case study paradigm. In this study, connection resulted from the mentoring process through communication with mentors, new social and work-related networks as well as within one's existing networks. In conclusion, data indicated that mentoring clearly has the potential to constitute the process of connection building among youth, and this process contributes to the development of their leadership capacities.
\end{abstract}

Keywords: Positive youth development, Mentoring, Youth leaders, Leadership development

\section{Introduction}

One of the core thrusts of a positive youth development approach to working with youth is aimed at unleashing youth's potential and readiness to lead. Youth development is described as an ongoing process to meet the physical needs and social demands in building youth competencies (Delgado, 2002), which in turn, promotes positive youth development (PYD) (Lerner et al., 2005). According to $\mathrm{Li}$ and Wang (2009), youth involvement in leadership activities is central to the youth development process. However, youth leadership development requires facilitated learning and role models that can be followed. Thus, mentoring has the potential in providing that kind of learning process. 
The PYD process serves as the basis for developing youth potential (Lerner et al., 2015), which principally require empirical understanding to reveal the potential of connection development on PYD among youth leaders through mentoring. In Malaysia, current national policies are being designed to address youth development needs (Razak, 2017). In line with the nation's vision of becoming a developed nation, TN50 aims to strengthen the leadership development process among youth as a strategy to boost Malaysia into a developed nation. However, there are indications that current youth leadership development efforts face several challenges.

According to Hastings, Human, and Bell (2011), as leaders, youth often fail to see themselves as decision-makers because some adult leaders fail to adequately pass on the skills, experience, opportunities and motivation needed to lead. Further, the continuity of guiding youth leadership, if not well planned, may inhibit young leaders from actively participating in the community development process, which can result in youth leaders lacking a sense of connection to their communities (Christens \& Dolan, 2011). Findings from the most recent Malaysian Youth Index (2015) indicate that this is currently the situation in Malaysia, whereby youths' readiness to lead is decreasing. Based on the situation, there are concerns involving the ability of Malaysian youth to lead. In order to empower young leaders to lead at a younger age, the National Youth Policy (2015) has formally reduced the age definition of youth from 15 to 40, to 15 to 30 . With a younger cohort of youth leaders taking on formal leadership roles within the country, there is much concern as to the leadership readiness of this group.

Scholars content that youth leadership development requires participative learning and role models that can be emulated (Lerner, Brittian \& Fay, 2007). According to Kay and Hinds (2012), mentoring has the potential to provide this type of learning process. Therefore, this qualitative study was conducted to explore how mentoring-based leadership development program enhanced the mentees' sense of connection to the community and youth stakeholders. The mentoring process studied also involved input from mentors and the Ministry of Youth and Sports Malaysia as the program planner and mentoring provider.

\section{Literature Review}

\section{Theories in Support of Leadership Mentoring}

Generally, mentoring is a relationship between two parties, in which one party (the mentor) guides the other (the mentee) through a period of change and towards an agreed objective or assists them to become acquainted with a new situation (Kay \& Hinds, 2012). Furthermore, leadership mentoring highlights the learning process of a one-to-one relationship, especially in traditional mentoring (Reagan-Porras, 2013), with the more senior and experienced individual as the mentor who supports the protégé's career development (Ragins \& Kram, 2007; Eller et al, 2013). Chaudhuri and Ghosh (2012), assert that traditional mentoring builds normative impression towards the process in which a mentor helps a mentee through a period of change.

Mentoring may take place in two situations, namely, formal and informal mentoring (Hezlett, 2005; 
DuBois et al., 2011), both with differences in learning development (Parise \& Forret, 2008; Pryce \& Keller, 2011). Kram's mentoring theory (1985) and Ragins and Kram (2007) assert that informal mentoring encourages protégé learning to develop naturally towards what is known and based on priority. Meanwhile, in formal mentoring, protégé and mentor work together through a few processes with support of an organization (Ragins \& Kram, 2007; Eby et al., 2013). According to Balcazar and Keys (2013), youth mentoring relationship becomes stronger when mentor and protégé consistently spend time together, in a significant mentoring duration. Rhodes (2005), Rhodes \& Dubois, (2008) and DuBois et al. (2011) suggest that learning through mentoring may contribute to the protégés' social-emotional, cognitive and identity development.

\section{Leadership Mentoring and Socialization from Communities of Practice}

In addition to providing support and personal guidance to unleash youth leader potentials, mentoring can facilitate socialization into the organization and community. Hence, to explore the process of leadership skill development, mentoring (Reagan-Porras, 2013) provides the perspective of acquiring knowledge and social skills, which also incorporates the process of legitimate peripheral participation (Lave \& Wenger, 1991; Wenger, 1998; Wenger et al., 2002). Lave and Wenger (1991) and Wenger (1998) noted that learning happened through participation and 'the sense of becoming' involved in the continuous construction of one's identity within various Communities of Practice (COP).

Learning in COP involves the acquisition and recognition of one's identity as a participant. It is not solely about acquiring cognitive knowledge and skills but also a learning process that enable novices to become members of a community which have been explained as a form of 'legitimate peripheral participation' (Lave \& Wenger, 1991). Legitimate peripheral participation enables new practitioners to take part in the actual everyday work practice despite having a 'peripheral' or a 'limited' degree of contribution and responsibility for the outcome of the task. From this process, the learner gains recognition as a member of a community and this community membership allows one to have the sense of belonging, engagement, inclusiveness and identity as a participant (Ismi et al., 2011). Legitimate peripheral participation refers to a route or a way in connection building which the new member may or in some situations must follow in order to engage themselves with the community's established members (Gherardi \& Nicolini, 2002).

\section{Positive Youth Development (PYD)}

Positive youth development (PYD) combines two main ideas. The first perspective is that youth possess inherent strengths, or assets, that form the foundation of their cognitive, emotional, social and behavioral development (Phelps et al., 2009; Gestsdottir et al., 2011). Second, their well-being will be achieved when their strengths are compatible with, and facilitated by appropriate behavioral reactions of their surrounding (Benson, Skala, Hamilton, \& Sesma, 2006), resulting in their healthy development. The individual development process in the PYD context involves adaptation of developmental regulations between youth strengths and asset development within a particular ecology (Phelps et al., 2009). Specifically, the PYD perspective can be narrowed down to the following: 
INTERNATIONAL JOURNAL OF ACADEMIC RESEARCH IN BUSINESS AND SOCIAL SCIENCES Vol. 8, No. 12, Dec, 2018, E-ISSN: 2222-6990 @ 2018 HRMARS

"The Positive Youth Development (PYD) perspective is an orientation to young people that has arisen because of interest among developmental scientists in using development systems, or dynamic, models of human behavior and development for understanding the plasticity of human development and the importance of relations between individuals and their real-world ecological settings as bases of variation in the course of human development"

(Sibereisen \& Lerner, 2007, p.3)

The term 'plasticity' refers to the potential for a more systematic change in human development, which instills positive elements (Lerner et al., 2005; Lerner, Brittian \& Fay, 2007). Therefore, the process of systematic change in youth development requires internal and external support (Lerner et al., 2005). According to Theokas et al. (2005), the combination of internal and external situations that shape individual development are known as individual and ecological assets, respectively (Lerner et al., 2010). Internal assets guide youth to make choices related to their strengths, such as future expectations, internal self-regulation and positive school engagement. External or ecological assets are found in one's environment such as positive experiences with others, and the institutions with which youth are involved (Lerner et al., 2012). When individual and external assets are maximized, human thriving results as conceptualized by the five core PYD outcomes known as the ' $5 \mathrm{Cs}^{\prime}$ (competence, confidence, character, connection and caring) (Lerner et al., 2005; 2015).

\section{PYD in the Mentoring Process}

From the mentor-based youth leadership program perspective, the knowledge formation process that results in positive behaviors and attitudes are an indicator of positive youth development (Lerner et al., 2005; Silbereisen \& Lerner, 2007; Lerner et al., 2011). Furthermore, knowledge formation process, behaviour and positive attitude of the participants cultivated from the systematic program development may be an indicator of the production of positive youth development (Lerner, 2005; Silbereisen \& Lerner, 2007; Lerner et al., 2011). Therefore, the aspect of planning youth development program is encouraged to take into account the current needs of youth (Cullen \& Bradford, 2012). A proper planning of developmental program will explain in detail the learning outcomes based on the objectives reached (Caffarella, 2002). This is the main element in planning leadership developmental program that focuses on youth. Effective mentoring enables the development of youth potential by providing them with the opportunity to develop life and leadership skills, which in turn, will enhance positive youth development (Lerner et al., 2013).

Mentoring is an approach guided by an enabler to encourage innovation, learning and continuous development (Kiltz et al., 2004). The dynamic mentoring theory explains that the principal of mentoring learning involves the relationship between mentor and protégé, whereby the protégé's learning is based on the observation of demonstration and learning support by the mentor (Balcazar \& Keys, 2013).Rhodes and DuBois (2008) assert that positive experience from the socio-emotion aspect in mentoring relationship may encourage youth to interact with others with an increased perception towards their parents, peers and adults within the protégés' social network more effectively. Besides that, the environmental factor between an individual, family and his/her 
surrounding also have an influence on mentoring relationship and the process of creating positive youth (Rhodes, 2005). Therefore, youth leadership development through mentoring is relevant to positive youth development.

Through mentoring, youth are given the opportunity to develop their leadership skills and build relationships with their mentors. The advantage obtained by the youth through leadership mentoring is associated with the criteria of effective youth development. In addition, mentoring provides the opportunity for youth to gain access using the ecological assets in the community in which they are involved. This will lead to the further attainment of the ' $5 C^{\prime}$ ' outcomes, which in the end, forms the contribution made by the youth (Lerner et al., 2013).

\section{Methods}

The study was conducted using a qualitative approach informed by the case study paradigm. Using the national youth leadership development mentoring program in Malaysia as the context for data collection, a total of 13 informants were involved in this study. They include mentors, protégés, the program organizer and training providers, and were identified using a purposive sampling approach. Data were collected through in-depth, semi-structured interviews and supported with relevant information from focus group discussions, participant observations, document analysis and field notes.

\section{Purposive Sampling}

The selection of participants for the study was based on the following criteria: a) informants were either protégés, mentors, organizers or training providers; b) protégé achieved high scores on their assessments throughout the mentoring process; c) informants' were willing to share learning experiences related to mentoring; and d) mentors were experienced in managing the mentoring processes. Snowball sampling was also carried out when participants introduced their friends to the study. Ultimately, the sample comprised those who were able and willing to provide necessary information on the issues under study (Merriam \& Tisdell, 2016).

\section{Data Collection and Analysis}

Researchers began the initial data analysis immediately after the first interview by analyzing and building categories and themes and then proceeded to the next interview. In order to facilitate the professional relationship between researchers and informants, the former established rapport to develop trust. First, the lead researcher moved into the field and identified a number of potential informants to be involved in the study. In several meetings, the researcher introduced the objectives of the study and sought the informants' consent to be involved in series of in-depth interviews. To strengthen the reliability of data obtained from the informants, the researchers sought their permission and cooperation to carry out observations of their activities.

The duration of each interview took between 50 minutes to 1 hour and 45 minutes. The researchers conducted each interview at the convenience of the informants. A total of 13 informants were involved in the study. As suggested by Creswell (2013), data were collected until saturation point, or 
INTERNATIONAL JOURNAL OF ACADEMIC RESEARCH IN BUSINESS AND SOCIAL SCIENCES

Vol. 8, No. 12, Dec, 2018, E-ISSN: 2222-6990 @ 2018 HRMARS

data redundancy, was achieved. Transcriptions of the interview sessions were examined several times in order to capture features of talk such as emphasis, speed, tone of voice, timing and pauses during interview. The data were further analyzed through coding and categorizing of themes using NVivo 11 software.

\section{Validity and Reliability}

Validity is a concept for measuring whether a study is reliable and trustworthy. It consists of four main aspects of credibility, transferability, dependability and conformability. As suggested by Merriam and Tisdell (2016) on how validity can be achieved, researchers were comparing between the description and explanation, and whether or not these explanations fit perfectly to the description. In addition, validity is also seen as a strength of qualitative research, whether the findings are accurate from the standpoint of the researcher, participant or readers (Creswell, 2013). In order to achieve validity and reliability of a study, the phenomenon should be assessed in depth. Validation and reliability also assist other researchers in studying issues related to this study.

According to Silverman (2013), validity and reliability in qualitative studies is very important to show the degree of consistency with which instances are assigned to the same category by different observers or by the same observer on different occasions. In this study, it can be achieved through the use of audit trail, member checks and peer examination. An audit trail refers to the steps adopted by the researchers at every stage of data collection and analysis, ensuring reliability of the study (Creswell 2013). Furthermore, researchers documented the preparation of the proposal, construction of interview protocol and questions, data collection as well as the process of analyzing the data. Member checks were used to reconnect the researchers to the informants to verify consistency in interpretation of the data (Silverman, 2013). The informants were contacted for clarification of facts of findings. As suggested by Creswell (2013), peer examination was also used to obtain feedback and consultation from a number of youth experts to verify data analysis and interpretation.

\section{Research Findings and Discussion}

From verbatim transcripts and significant statements extracted, the findings indicate how protégés expanded their connection through the mentoring process. In this study, connection resulted from the mentoring process in three ways; 1 ) through communication with mentors; 2) through new social and work-related networks; and 3) through strengthening existing networks. Based on participant observations, mentoring provides opportunities for the protégé to communicate directly with their mentors. The study also found that mentoring has opened the access to protégé in network construction and at the same time mentor has strengthened the network. Based on interview findings, protégé recognize the role of mentor in providing the connection platform, as recognized by Protégé 1:

"I admit that when I'm under my mentor and colleagues in his office, I had given many opportunities by them to collaborate with many parties. I got a new network for example with a person in charge at National Sports Institute, with the top gun of the Malaysian Youth Council. Most of the network when I was handling Fit Malaysia. So... mentoring was 
beneficial in strengthening my network."

Under these circumstances in mentoring process, protégé also learned through the organizational members, not just only one to one relationship between mentor and protégé. The learning process through activity system that allow the COP to translate something on practical experience from group activities and also influence the descriptive thinking and human behavior. Individuals involved in a group or community can be influenced by the effects of the past experience to form the activity (Lofthouse \& Leat, 2013). Thus, the activity system has strong relationship on what they have been practiced in a community as a community of practice (Singh, Hawkins \& Whymark, 2009). Community in organization also enhanced protégé's learning during the process of mentoring. Therefore, protégé is easy to adjust the mentoring process to be more comfortable in learning community.

Mentor is a medium for linking protégé with stakeholders and other shareholders to create a wider network of partnerships to the organization. Protégé 2 stated that:

"... in the ministry, there are various parties and agencies that work together and assist the minister in implementing policies. All of them are ministries. I am indirectly involved mentor in strengthening the cooperation. ... ".

During the mentoring process, the protégé was also involved in various series of discussions and negotiations with mentor. Through that platform, the protégé can build a wider network of disciplines in the same expertise. Protégé 3 stated that:

“...many companies and consultants who have consulted with the ministry, luckily I can join the discussion. I do not expect that I can build my network and contacts with professional person in the same field with me. I will definitely take advantage of that opportunity. ...".

Through mentoring, youth are given the opportunity to develop skills, shape youth leadership and continuity hence maintain the connection between the youth (protégé) and adults (mentor). The advantage obtained by the youth through leadership mentoring is associated with the effective youth development criteria. Besides that, it provides the opportunity for the youth to gain access through the ecological asset via the community they are involved in and this will directly develop each of the '5Cs' especially connection element in developing positive youth (Lerner et al., 2011; Lerner et al., 2012).

Indirectly, connection through mentoring enable protégé to be easily identified by community leaders. Protégé 4 also said the same thing about leadership learning through connection from mentor:

"... During mentoring, I joined my mentor while he went down to visit various areas under his parliament. It can be said every time he visits the area, I will join and together with him. 
INTERNATIONAL JOURNAL OF ACADEMIC RESEARCH IN BUSINESS AND SOCIAL SCIENCES Vol. 8, No. 12, Dec, 2018, E-ISSN: 2222-6990 @ 2018 HRMARS

Indirectly, I can build my connection and networks with local leaders, community leaders and youth movement leaders as well. ... ".

The connection that has been built by protégé through access from mentor has opened up the space to identify leadership talent and more recognizable society. Indirectly, the protégé is more easily known his potential in leadership. Protégé 5 describes the indirect benefits of a mentor's provided platform by stating:

"... Although I was active in the youth movement in Segamat, but in my mentor area I was able to get the support. Because in the past I have connection with them through my mentor. They recognize name there, people know. That time there was no intention of contesting as a member of the youth parliament. It's easy for me. When I want to contest for youth member of parliament, this network help my campaign. That's the effect when we are placed under somebody as a mentor. People will know us easily. ...".

Access obtained from a mentor-owned network helps accelerate the development of their ecological assets that help to improve PYD. Agans et al. (2014) states that youth are often left out in the context of social activity and positive connection. Therefore, the construction of an external network is necessary for the youth to exhibit positive values that induce bonding with other individuals and institutions as well as helping to build youth capacity in connection towards PYD (Agans et al., 2014). Provision of a platform by mentors helps to bond mutually beneficial relationships between individuals and peers, institutions and communities.

\section{Conclusion}

Previous studies suggest that mentoring can assist in the formation of new leadership potentials among youth, but few studies have explored how this occurs. This study was conducted to explore how youth, who participated in leadership programs that incorporate mentoring, learned about and established new networks related to their work as leaders, thus developing their connection to others. The study findings indicate that connection occurs not only between mentors and protégés, but also in the locus of the mentor's organizational community. Thus learning and connection is not limited only to what occurs within the one-to-one mentor-protégé dyad. This study also found that connection - as one of the '5Cs' in Positive Youth Development (PYD) - had been developed youth leaders in strengthening their network and providing wider exposure through mentoring.

Generally, positive values of youth leaders as discussed from the PYD perspective have also reviewed traditional youth services, which also include services for the community and youth stakeholders Therefore, it can be seen that the PYD values have a strong relationship with the leadership values shaped through mentoring. PYD results from a strong bond between young leaders and the leadership community of practice that is engaged in the mentoring process. More initiatives that link academic institutions, public sector organizations and corporations in the form of mentoring should be provided to youth to enhance their leadership learning and develop in them the holistic, balanced and entrepreneurial traits as espoused in the TN 50 initiative. 
INTERNATIONAL JOURNAL OF ACADEMIC RESEARCH IN BUSINESS AND SOCIAL SCIENCES

Vol. 8, No. 12, Dec, 2018, E-ISSN: 2222-6990 @ 2018 HRMARS

\section{References}

Agans, J. P., Champine, R. B., DeSouza, L. M., Mueller, M. K., Johnson, S. K., \& Lerner, R. M. (2014). Activity involvement as an ecological asset: Profiles of participation and youth outcomes. Journal of Youth and Adolescence, 43, 919-932. http://doi.org/10.1007/s10964-014-0091-1 Benson, P. L., Scales, P. C., Hamilton, S. F., \& Sesma, A., Jr. (2006). Positive youth development: Theory, research, and applications. In R. M. Lerner (Ed.), Theoretical models of human development. Volume 1 of Handbook of Child Psychology (6th ed.) (pp. 894-941). Editors-inchief: W. Damon \& R. M. Lerner. Hoboken, NJ: Wiley.

Christens, B. D., \& Dolan, T. (2011). Interweaving Youth Development, Community Development, and Social Change Through Youth Organizing. Youth \& Society, 43, 528-548. http://doi.org/10.1177/0044118X10383647

Creswell, J. W. (2013). Qualitative inquiry and research design: Choosing among five approaches (3rd ed.). Thousand Oaks, CA: Sage Publications Inc.

Delgado, M. (2002). New frontiers for youth development in the twenty-first century revitalizing youth development. New York: Columbia University Press.

Eller, L. S., Lev, E. L., \& Feurer, A. (2013). Key components of an effective mentoring relationship: A qualitative study. Nurse Education Today, 13(1), 1-6.

Gestsdottir, S., Urban, J. B., Edmond, P., Lerner, J. V, \& Lerner, R. M. (2011). Intentional Self-Regulation, Ecological Assets, and Thriving in Adolescence: A Developmental Systems Model. In R. M. Lerner, J. V. Lerner, E. P. Bowers, S. Lewin-Bizan, S. Gestsdottir, \& J. B. Urban (Eds.), Thriving in childhood and adolescence: The Role of self-regulation processes. New Directions for Child and Adolescence Development, 133, 61-76.

Hastings, L. J., Human, N., \& Bell, L. C. (2011). Developing a Paradigm Model of Youth Leadership Development and Community Engagement: A Grounded Theory. Journal of Agricultural Education, 52(1), 19-29. doi:10.5032/jae.2011.01019

Kay, D., \& Hinds, R. (2012). A practical guide to mentoring: Using coaching and mentoring skills to help others achieve their goals (5th ed.). Oxford: How to Books Ltd.

Lerner, R.M., Lerner, J.V., Almerigi, J., Theokas, C., Phelps, E., Gestsdottir, S., Naudeau, S., Jelicic, H., Alberts, A.E., Ma, L., Smith, L.M., Bobek, D.L., Richman-Raphael, D., Simpson, I., Christiansen, E.D., \& von Eye, A. (2005). Positive youth development, participation in community youth development programs, and community contributions of fifth grade adolescents: Findings from the first wave of the $4-\mathrm{H}$ study of positive youth development. Journal of Early Adolescence. 25(1): 17-71.

Lerner, R. M., Brittian, A., \& Fay, K. (2007). Mentoring: A Key Resource for Promoting Positive Youth Development. Research in Action, 1(1), 3-15.

Lerner, R. M., von Eye, A., Lerner, J. V., Lewin-Bizan, S., \& Bowers, E. P. (2010). The meaning and measurement of thriving: A view of issues. Journal of Youth and Adolescence, 39 (7), 707-719.

Lerner, R. M., Lerner, J. V., Lewin-Bizan, S., Bowers, E. P., Boyd, M., Mueller, M., Schmid, K., Napolitano, C. (2011). Positive youth development: Processes, programs, and problematics. Journal of Youth Development, 6(3), 40-64.

Lerner, R. M., Bowers, E. P., Geldholf, G. J., Gestsdottir, S., \& Desouza, L. (2012). Promoting positive 
INTERNATIONAL JOURNAL OF ACADEMIC RESEARCH IN BUSINESS AND SOCIAL SCIENCES

Vol. 8, No. 12, Dec, 2018, E-ISSN: 2222-6990 @ 2018 HRMARS

youth development in the face of contextual changes and challenges: The roles of individual strengths and ecological assets. New Directions for Youth Development, 135(1), 119-28. doi: 10.1002/yd.20034

Lerner, R. M., Napolitano, C. M., Boyd, M. J., Mueller, M. K., \& Callina, K. S. (2013). Mentoring and positive youth development. In D. L. DuBois, \& M. J. Karcher (Eds.), The handbook of youth mentoring (2nd ed.). (pp. 17-27). Thousand Oaks: Sage Publications Inc.

Lerner, R. M., Lerner, J. V., Bowers, E. P. \& Geldholf, G. J. (2015). Positive youth development: A relational developmental systems model. In R.M. Lerner, W. F. Overton, \& P. C. M. Molenaar (Eds.), The handbook of child psychology and developmental science (7th ed.). (pp. 607-651). New Jersey: John Wiley and Sons Inc.

Li, G., \& Wang, B. (2009). Adolescent Leadership Development: A Review. International Conference on Teaching and Computational Science (WTCS 2009) Proceedings (pp. 753-758). Shenzhen: Advances in Intelligent and Soft Computing.

Malaysian Youth Index (2015). Malaysian Institute for Youth Research (IYRES) Putrajaya: Ministry of Youth and Sports, Malaysia.

Merriam, S. B., \& Tisdell (2016). Qualitative research: A guide to design and implementation (4th ed.). San Francisco, CA: Jossey-Bass.

Mohd Najib Abdul Razak. (2017). Transformasi Nasional 2050. Retrieved from https://www.najibrazak.com/en/blog/transformasi-nasional-2050/

Phelps, E., Zimmerman, S., Warren, A. E. A., Jeličič, H., von Eye, A., \& Lerner, R. M. (2009). The structure and developmental course of Positive Youth Development (PYD) in early adolescence: Implications for theory and practice. Journal of Applied Developmental Psychology, 30(5), 571584.

Ragins, B. R., \& Kram, K. E. (2007). The roots and meaning of mentoring. In B. R. Ragins, \& K. E. Kram (Eds.), The handbook of mentoring at work: Theory, research and practice (pp. 3-17). Thousand Oaks: Sage Publications Inc.

Reagan-Porras, L. L. (2013). Dynamic duos: A case review of effective mentoring program evaluations. Journal of Applied Social Science, 7(2), 208-219. doi:10.1177/1936724412467019

Silbereisen, R. K., \& Lerner, R. M. (2007). Approaches to positive youth development. London: Sage Publications.

Silverman, D. (2013). Doing qualitative research: A practical handbook. Thousand Oaks: Sage Publications Inc.

Theokas, C. (2005). Conceptualizing and modeling individual and ecological asset components of thriving in early adolescence. The Journal of Early Adolescence, 25(1), 113-143. doi:10.1177/0272431604272460 